\title{
Electoral Control when Policies are for Sale
}

\author{
ETIENNE FARVAQUE \\ GAËL LAGADEC
}

CESIFO WORKING PAPER No. 2522

CATEgory 2: Public Choice

JANUARY 2009
An electronic version of the paper may be downloaded
- from the SSRN website: www.SSRN.com
- from the RePEc website: $\quad$ www.RePEc.org
- from the CESifo website: www.CESifo-group.org/wp




\title{
Electoral Control when Policies are for Sale
}

\begin{abstract}
This article analyses the dynamics of electoral promises, building on an electoral competition model with endogenous policies. It extends the Grossman-Helpman (1994) model [Grossman G., Helpman E. [1994], "Protection for sale", American Economic Review, 84, 4, 833-850] to include sanctions from the electorate and lobbies when the incumbent does not satisfy the expected performance she promised to deliver. This framework allows to deal with the intertemporal dimension needed to understand the prevalent cycle of promises, disappointment, new promises, new disappointment ....
\end{abstract}

JEL Code: D72, P16.

Keywords: lobbies, promises, elections, electoral competition, lies.

\author{
Etienne Farvaque \\ Equippe \\ University of Lille 1 \\ Faculty of Economics \\ 59655 Villeneuve d'Ascq Cedex \\ France \\ etienne.farvaque@univ-lille1.fr
}

\author{
Gaël Lagadec \\ Department of Economics \\ University of New Caledonia \\ BPR4 - 98851 Nouméa Cedex \\ New Caledonia \\ lagadec@univ-nc.nc
}

First author has benefited from a grant from the French Agence Nationale de la Recherche (ANR, $n^{\circ}$ FRAL 022). We would like to thank Corinna Ahlfeld, Agnès Bénassy-Quéré, Felix Bierbrauer, Simon Burke, Matthieu Crozet, Marina Della Giusta, Uma Kambhampati, Ricardo Magnani, Stephen McKnight, Christian Nygaard, Sandra Poncet, Catherine Ris, Antonio Savoia, participants to the PGPPE 08 Workshop (Bonn), to a CEPII external seminar and to a Faculty seminar at the University of Reading. The usual disclaimer applies. 


\section{Electoral control when policies are for sale}

\section{Introduction and background literature}

Is an electoral campaign a tool to pledge economic policies to come or to flatter voters by promising economic policies that may not be implemented? Another way to ask the question would be: does politics have to be disappointing? It is crystal clear that the answer to that is essential to maintaining legitimate democracies. Indeed, should politics be necessarily and systematically disappointing, then the tendency not to vote that exists in some democracies could develop to the point that politics would be determined by a small number of voters whose characteristics would be either altruism or instead belonging to lobbies that would be likely to strongly influence the economic policies implemented (in their best interest).

In this article, we are studying, within the framework of electoral competition in the presence of endogenous lobbies, the dynamics of election promises. If economic policies can be influenced by lobbies, then we must analyse the dynamics of the elected representatives' promises and achievements. In return, the presence of the lobbies will be affected by the dynamics of promises and we integrate this endogenous constitution of lobbies in the analysis. Thus our study stands at the confluence of several interrelated literatures (see the synthesis by zones in figure 1).

A first strand of the literature on endogenous economic policies can be characterized by the way elections are taken into account, or not: either, starting from Peltzman (1976) and Hillman and Ursprung (1988), election is not explicitly taken into consideration, or, in the tradition of Brock and Magee (1978), electoral competition lies at the core of the political game.

Another strand of the literature can be termed "the contribution approach", and it most often relies on Grossman and Helpman (1994). Their model has become the workhorse in this approach, notably when studying the political economy of trade. Its attraction comes notably from the fact that the model has clear-cut predictions on the relation between protection and the import penetration. This facilitates the empirical strategy, and has permitted to verify the empirical relevance of the approach, as was for example demonstrated by Goldberg and Maggi (1999), Gawande and Bandyopadhyay (2000) ${ }^{1}$, Mitra et al. (2002), Eicher and Osang (2002), McCalman (2004), Lopez and Matschke (2006).

However, both the theory and its empirical validation have recently come under attack. The link between contributions received from lobbies and policies implemented by politicians has been questioned by, notably, Ansolobehere et al. (2003), while the empirical strategies have been criticized by Mitra et al. (2006) and Kee et al. (2007). [The approach through contributions, which doesn't take the election into consideration, is at the intersection of zones B, C, D \& E of figure 1.]

\footnotetext{
${ }^{1}$ Gawande and Bandyopadhyay (2000) show that, following the Grossman and Helpman model predictions, US protection is sold to lobbies. They show that the lobbies spending compensates the government from deadweight loss from protection and explain the low level of US protection as resulting from preferences of the government, placing similar weight on total net welfare relative to lobbying spending. They also show that in the case of rival lobbies, the competition increases the contributions and that lobbies spending clearly depends on the strength to their rivals.
} 
Figure 1. Existing strands of the literature

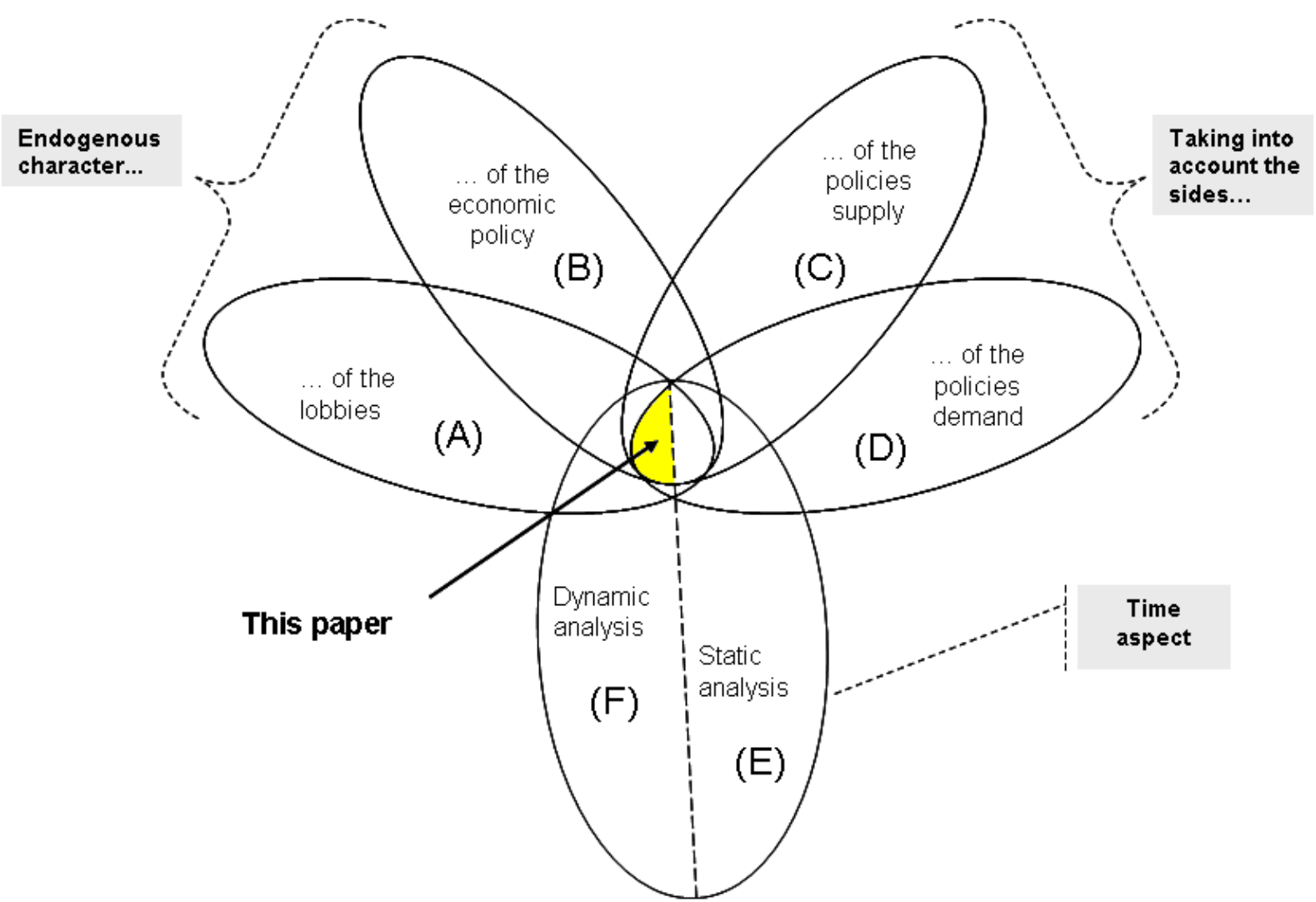

The main criticism to Grossman and Helpman's approach (1994) is of ignoring the election process despite the lobbies' role in the process ${ }^{2}$. Looking at Ansolabehere et al. (2003) sheds light on the importance of this criticism. Trying to answer to an old question attributed to Tullock (1972) ("why is there so little money in US politics?"), the authors first consider that, given the value of policies at stake, interest groups should give more. Second, focusing on PAC contributions they show relatively few effects on voting behaviour. According to them, this could suggest that policies are not for sale.

But two other explanations may rebute this statement. (1) Contributions especially target very specific policies (e.g. commercial protection for one industry), and then the ratio global value of policies / contributions is not a relevant way to assess the presence of money in politics. (2) Lobbies want to affect election outcomes rather than changing position of politicians, as Ansolabehere et al. (2003) themselves state, which mean that the best analyzing tool is electoral competition.

\footnotetext{
${ }^{2}$ Grossman and Helpman themselves consider (1994, p. 834) that the electoral competition model is better suited to the analysis of the trade policy major shaping whereas their model is more suitable for a detailed analysis (by sectors) of this policy.
} 
A third strand of the literature focuses on another limit, i.e. the strictly exogenous character of the lobbies. Most generally, lobbying is modelled as a "menu-auction" where exogenouslyconstituted lobbies offer to politicians contribution schedules that are binding promises of payments, conditional on the chosen policy (see e.g. Bernhein and Winston 1986, Grossman and Helpman 1994). To get round this limit, some works have integrated endogenous lobbies (see for example Findlay and Wellisz $1982^{3}$, or Felli and Merlo $2002^{4}$ ). Implemented sectorial policies are then considered as a growing function of the contributions received. But then, part of the political game is often missing. [Those works are at the intersection of zones A, C, and E of figure 1.]

More importantly, whatever the strand of the literature considered, a shortcoming largely present in literature is the static framework of the political economic analysis. Relatively few works situated in the field of endogenous protection integrate the notion of time, or the dynamics of election promises. Cairns (1989), taking up Becker's analysis (1983), studies the compared welfare effects of rent seeking in static and dynamic frameworks. Yet the analysis deals only with the lobby's side. The side of policies demand (voters) is not taken into consideration and the supply side (politicians) is considered as given. Moreover the election is not explicitly taken into consideration (in this case, the electorate is not a variable which justifies, within this analysis framework, focusing the reflexion on the role of lobbies). [Cairns's analysis is at the intersection of zones B, C, and F of figure1.]

In Banks (1990), time consideration does not translate into an intertemporal analysis since the model is a one-period one. The time aspect is only present as a background, justifying the cost of the lie: the author considers that the voters can sanction the candidates for their past lies (Banks 1990, p. 310). [Banks' analysis is at the intersection of zones B, C, D \& E of figure 1.]

Ward (1993) integrates time in his analysis but in the background only: time is introduced only to link the finite aspect of politicians'careers to the difficulty to cooperate at the international level (Ward 1993, p. 230). [Ward's analysis is at the intersection of zones C \& E of figure 1.]

Wirl (1994) points out the weakness of the static analysis by asserting that the dynamic aspect of lobbying is its most basic characteristics. The author, attempting to answer the same question as Ansolabehere et al. (2003), modelizes lobbying as competition between two groups (farmers and consumers) in relation to the same criterion (political favour). The main conclusion of the analysis is that, in a dynamic framework, one lobby restricts its effort out of fear of reprisals from the other lobby. Yet the election is not taken into account (we are in effect in an analysis framework where lobbying is continuous, so the model can be static, and is de facto close to the one shown by Peltzman, 1976, in terms of regulation or of Grossman and Helpman's, 1994) ${ }^{5}$. [Wirl's analysis is at the intersection of zones B \& E of figure 1.]

\footnotetext{
${ }^{3}$ Findlay and Wellisz (1982) consider two lobbies (one protectionist and one supporting free trade), exerting contradictory pressures. The tariff is a function of the effort balance (i.e. resources invested in the political process) of the competing lobbies. The approach however stumbles on a mathematical impossibility: the shape of reaction curves of each group is not determined, forbidding knowing whether the balance is stable or even if it does exist.

${ }^{4}$ In Felli and Merlo (2002), the incumbent chooses the lobbies participating in the political game. So the coalition of lobbies depends on the preferences of the incumbent (supposed to choose lobbies with different preferences to its own in order to maximise contributions).

Besides, the hypothesis according to which consumers organise in lobbies (and express themselves independently from the electoral framework) is contradictory with what we know, since Olson (1966) notably, about the difficulty of collective action for large groups (as a matter of fact, the point is recognised by Wirl, 1994, p. 308).
} 
The corollary of the static analysis is that the phases of the political game are actually simultaneous. Conversely, in an intertemporal framework, nothing prevents a separation between these phases. Thus the payment by the lobby of a contribution, the announcement and then the implementation of the policy by the political party do not occur at the same time. So it seems necessary to introduce the fact that the game phases are linked by the players' commitments, relying particularly on trust or credibility. At that point an analysis of the lie in politics is becoming essential.

Aragones et al. (2007) demonstrate that the most accurate perspective to analyze political games is the dynamic one ${ }^{6}$. They make the hypothesis that when a candidate lies the electors punish her by never believing her future promises. This punishment for reneging is rather extreme (as the authors recognize) which can bias the results of the model. Such a bias is indeed recurrent in taking the political lie into account.

Two possibilities are competing here. Either promises are binding, and the policy is determined at the time of the campaign (the lie is nil); or the promises are worthless, and the policy is actually determined after election (the lie is gratuitous). According to Persson and Tabellini (2000): "It is somewhat schizophrenic to study either extremes: where promises have no meaning or where they are all that matter. To bridge the two models is an important challenge".

The model proposed in this paper is an attempt to get to this challenge ${ }^{7}$, in that we make the original Grossman-Helpman model and reality closer, embedding the re-election constraint in the policymaker's reaction function, so as to take into account the fact that contributions may evolve in response to unsatisfied expectations from the incumbent.

Other attempts have been made, of course, each with their own limitations. In Austen-Smith and Banks (1989), the incumbent's performance depends on her effort (a feature that is also present in this paper). They then show that, as voters exert a pressure on the incumbent to fulfil her promises, the incumbent has strong incentives to comply.

Banks (1990) also considers electoral promises in a dynamic framework, but without linking the policies to the vested interests they may satisfy. The same limit applies to the models based, e.g., on the frameworks developed by Ferejohn $(1986)^{8}$ or Rogoff (1990), where electoral support is not taken into consideration.

Aragones et al. (2007) show, in an infinite-horizon model, that politicians have an interest to keep their promises, so as to create a reputation towards voters playing trigger strategies. Harrington (1993) also studies political promises, but in a model where politicians pander promises to electoral beliefs, hence leading to the conclusion that candidates will have an interest in being truthful if they want to have a chance to be re-elected in the second electoral period of the model.

\footnotetext{
6 "If voters have rational expectations, no campaign promise can alter voters' beliefs about what action will be taken by a candidate if he is elected. If there were any statement that did alter beliefs in a way that increased the probability of election, the candidate would make such a statement (...) Hence no campaign statement can convey information that alters the chance of election. When we move from the case of a single election to multiple elections, campaign promises may be costly (...) in a repeated game" (Aragones et al., 2007).

7 Another attempt is due to Bennedsen and Feldmann (2006), where lobbying is a continuous action, but implemented without considering electoral deadlines.

${ }^{8}$ Ferejohn's (1986) analysis relies notably on the divergence between politicians'annoncements and actions.
} 
Callander and Wilkie (2007) develop Banks' model (1990) by putting political lies at the core of the analysis. At that point, they notably modelize gratuitous lies as specific cases of usually costly lies. Though a one-period model, their analysis is not far from ours. Yet, whereas we integrate lies and their consequences into the endogenous economic policy, Callander and Wilkie (2007) is more typical of the electoral competition approach (to which extent does politicians' ability to lie affect the likeliness of being elected?). [Those analyses lie at the intersection of zones B, C, D \& E of figure 1.]

At this point, it is probably useful to state what the main characteristics of our approach are, in relation of these different strands of literature. We do not consider a homogenous electorate, and we integrate lobbies'actions aiming at getting specific policies favouring their own interest. Secondly, we focus our analysis on the conditions in which politicians can disown their commitments, thus revealing, in our framework ${ }^{9}$, the basic reasons for political lies as well as their consequences (re-election, time account). Thirdly, we are using a model close to the models presenting lobbying as an auction process, yet in our model the formation of lobbies is, at least to some extent, endogenous. Finally, our model is an intertemporal model of endogenous economic policies taking into consideration both the side of the supply and of the demand. Hence, though relying on a framework derived from the contributions approach, the paper is also related to the part of the literature that deals with electoral competition and campaign promises. As a consequence, uncertainty is introduced as a central element of the process. Deception and its cost (neither nil nor infinite) will be determined endogenously by the model. Figure 1 shows where such an approach stands in relation to literature.

The article is structured as follows. The following section details the hypotheses and microfoundations of the model. Section 3 exposes and solves the intertemporal program, while in section 4 we derive the equilibrium of the game and discuss the results. The last section concludes and provides hints for further research.

\section{The model}

\subsection{Foundations}

We are reformulating here the Grossman and Helpman's model (typical of the Ricardo-Viner framework) while simplifying it and also generalizing it to tax policies as a whole. Individuals have identical additive utility functions in the shape:

$$
U_{t}=\theta_{L}+\sum U\left(\theta_{x_{i}}\right)
$$

\footnotetext{
${ }^{9}$ Note that our approach, although focusing on time constraint and modifications of political behaviours is not an informational theory. That is we do not accept political contribution to be welfare improving. First, Browning (1974) considered the beneficial impact of lobbying through the transmission of information. Others, such as Baldwin (1982), Laband and Sophocleus (1988), Austen-Smith and Wright (1992), who present a model of informational lobbying accept that lobbies spending also has a positive impact on social welfare. See in the same stream Lagerlöf (2006).
} 
$\theta_{\mathrm{Z}}$ is consumption of good $\mathrm{Z}$, which serves as standard with a domestic and international price normalized to 1 . $\theta_{x i}$ is the consumption of $\operatorname{good} X_{i}(i=1,2, \ldots, n)$.

The utility functions are differentiable, rising and strictly concave. The standard good is produced from labour only (a work unit produces a good unit). The other goods are produced each by labour and a specific factor. All prices are measured in accordance with the standard. The wage rate is then equal to 1 .

In the way of Ederington and Minier (2008), we extend Grossman and Helpman's standard model so as to consider that the government exerts both trade policies (creating a gap between domestic and international prices) and production policies (creating a gap between production and consumption domestic prices).

$P_{i, t}=\left(P_{1}, P_{2}, \ldots, P_{n}\right)$ is the vector of domestic prices of non standard goods $\pi_{i, t}=\left(\pi_{1}, \pi_{2}, \ldots, \pi_{n}\right)$ is the vector of international prices of non standard goods.

$\hat{r}_{i, t}=\left(\hat{r}_{1}, \hat{r}_{2}, \ldots, \hat{r}_{n}\right)$ is the vector of trade taxes (a tariff on imports or a subsidy for exports if superior to 1$)$.

$\tilde{r}_{i, t}=\left(\tilde{r}_{1}, \tilde{r}_{2}, \ldots, \tilde{r}_{n}\right)$ is the vector of taxes / subsidies for production (subsidies if superior to 1).

$r_{i}$ is the vector of tax policy, with $r_{i, t}=\hat{r}_{i, t} \cdot \tilde{r}_{i, t}$. So we have: $P_{i, t}=\pi_{i} \cdot \hat{r}_{i, t} \cdot \tilde{r}_{i, t}$

We consider two elections, the first one occurring in period $t$. Each period covers the campaign before election, the election proper and the ensuing mandate ${ }^{10}$. The election is run notably around real or anticipated economic competence ${ }^{11}$. The competence is normalized to belong to the $[0 ; 1]$ interval. It corresponds to the quality of the answer to a group's expectations. Thus if none of a group's expectations is satisfied, the elected representative's competence will be perceived by the group members as equal to nought.

The likeliness of an election depends, a priori, on promises made by the candidates and the contributions they received. At period $t$, we suppose that the probability to be elected in $t, \rho_{t}$, depends on contributions only ${ }^{12}$. Indeed, the announcement the candidate made does not match her programme exactly, it matches what the opinion knows of this programme. In this way a candidate who received no contribution will be unable to publicize her programme whereas for a candidate who received an almost infinite amount of contributions the likeliness to be elected will get closer to the unit. So we have:

$$
\rho_{t}=\frac{C_{t}}{1+C_{t}}
$$

\footnotetext{
${ }^{10}$ Period $t+1$ starts at the end of the mandate of period $t$, at the beginning of the election campaign in which the government will seek re-election.

${ }^{11}$ For all that the model is not one of electoral prediction. Even if the probability of re-election is a growing function of the contributions received, we consider that the election proper depends on other parameters (some non random) that are not formalised here.

${ }^{12}$ Nevertheless this does not strictly mean that the election at period $t$ does not depend on the population, but the part of the likeliness of an election linked to the population at the first period corresponds to exogenous parameters (population's preference, the candidate's relative charactéristics, hazard).
} 
Taking the contributions into account leads one to distinguish two cases.

Case 1. The policy announced to the lobbies is determined ex-ante according to the demands of industrial lobbies (typically: in competition with importations). Then the micro foundations are characteristic of the Grossman and Helpman's framework.

The consumer's surplus is the variable chosen to appreciate the voters'welfare:

$$
\begin{aligned}
& S_{t}\left(P_{i, t}\right)=\sum_{i} U_{t}\left(d_{i}\left(P_{i, t}\right)\right)-\sum_{i} P_{i, t} d_{i}\left(P_{i, t}\right) \\
& S_{t}\left(r_{i, t} \pi_{i, t}\right)=\sum_{i} U_{t}\left(d_{i}\left(r_{i, t} \pi_{i, t}\right)\right)-\sum_{i} r_{i, t} \pi_{i, t} d_{i}\left(r_{i, t} \pi_{i, t}\right)
\end{aligned}
$$

with $d_{i}$ the individual demand in good $i$.

The tax policy also determines the tax revenue $(R)$. We write that $Q_{i}$ represents the produced domestic quantity of good $Q$, and $N$ represents the whole population. We have the tax revenue per capita:

$$
R_{t}(r, \pi)=\sum_{i}\left[\left(\hat{r}_{i, t}-1\right) \pi_{i, t}\left(d_{i}\left(r_{i, t} \pi_{i, t}\right)-\frac{1}{N} Q_{i, t}\left(r_{i, t} \pi_{i, t}\right)\right)+\left(\tilde{r}_{i, t}-1\right) \frac{Q_{i, t}}{N}\right]
$$

where $d_{i}\left(r_{i, t} \pi_{i, t}\right)-\frac{1}{N} Q_{i, t}\left(r_{i, t} \pi_{i, t}\right)$ represents the demand minus the production, i.e.the imports. A customs tariff exists when at least one factor of production specific in the industry is present. The tariff (subsidy) also determines the rent got from this factor of production. Given $\Pi_{i}\left(P_{i}\right)$ the rent agreggate entailed by tariff (subsidy).

The general welfare $(\omega)$ is the summation of these three elements to which we add the dotation in labour $(l)$ :

$$
\omega_{t}\left(r_{t}, \pi_{t}\right)=l_{t}+\sum_{i} \prod_{i}\left(r_{i, t} \pi_{i, t}\right)+R_{t}\left(r_{t}, \pi_{t}\right)+S_{t}\left(r_{t} \pi_{t}\right)
$$

The lobbies'welfare is expressed as:

$$
\omega_{i=i_{L} ; t}\left(r_{t}, \pi_{t}\right)=l_{i=i_{L} ; t}+\prod_{i=i_{L} ; t}\left(r_{i=i_{L} ; t} \pi_{i=i_{L} ; t}\right)+\chi_{i=i_{L} ; t}\left[R_{t}\left(r_{t}, \pi_{t}\right)+S_{t}\left(r_{t} \pi_{t}\right)\right]
$$

with $i_{L}$ the sector politically organized in the way of Grossman and Helpman. $l$ represents the supply of labour, $\Pi$ represents the productivity of the specific factor, $\chi$ represents the part in the population of the lobby's members, $R$ represents the tax revenue, and $S$ represents the consumer's surplus.

The lobbies want to maximize their welfare, net of the contributions given to the government, i.e. : $V_{i, t}=\omega_{i, t}(r, \pi)-C_{i, t}(r,$. 
The contributions plan links an announced policy and contributions for each sector is: $C_{i, t}=\phi_{i, t} \cdot \omega_{i, t}$, with $\phi_{i, t} \in[0,1]$.

Note that, globally speaking, the lobby offers two plans of contributions, one to the government and one to the opposition. Yet, if the two candidates belong to different parties clearly situated on either side of the political stage, at least in terms of the distribution criterion, then we can expect one of these contribution plans to be empty ${ }^{13}$, which corresponds to $\phi_{i, t}=0$. Then we can write the utility function of the lobby:

$$
V_{i, t}=\left(1-\phi_{i, t}\right) \cdot l_{i, t}+\left(1-\phi_{i, t}\right) \cdot \Pi_{i, t}\left(r_{i, t}, \pi_{i, t}\right)+\left(1-\phi_{i, t}\right) \cdot \chi_{i, t}(R(r, \pi)+S(r, \pi))
$$

In the typical situation of a sector politically organised since it is in competition with imports, the function is rewritten ${ }^{14}$ :

$$
V_{i, t}=\left(1-\phi_{i, t}\right) \cdot l_{i, t}+\left(1-\phi_{i, t}\right) \cdot \Pi_{i, t}\left(r_{i, t}, \pi_{i, t}\right)+\left(1-\phi_{i, t}\right) \cdot \chi_{i, t}\left(\left(r_{i, t}-1\right) \cdot M_{i, t}\left(r_{i, t}\right)+S\left(r_{i, t}^{l}, \pi_{i, t}\right)\right)
$$

with $M_{i}$ the quantity of imported good $i$.

The maximisation of the lobby's objective function is:

$$
\frac{\partial V_{i}}{\partial r_{i, t}}=\left(1-\phi_{i, t}\right) \cdot \Pi_{i, t}{ }^{\prime}\left(r_{i, t}, \pi_{i, t}\right)+\left(1-\phi_{i, t}\right) \cdot \chi_{i, t}\left(\left(r_{i, t}-1\right) M_{i, t}{ }^{\prime}\left(r_{i, t}\right)+M_{i, t}\left(r_{i, t}\right)+S_{i, t}{ }^{\prime}\left(r_{i, t}, \pi_{i, t}\right)\right)=0
$$

and (by Hotelling's Lemma $)^{15}$ :

$\left(1-\phi_{i, t}\right) \cdot X_{i, t}+\left(1-\phi_{i, t}\right) \cdot \chi_{i, t}\left(r_{i, t}-1\right) M_{i, t}{ }^{\prime}\left(r_{i, t}\right)=-\left(1-\phi_{i, t}\right) \cdot \chi_{i, t}\left(M_{i, t}\left(r_{i, t}\right)+S_{i, t}{ }^{\prime}\left(r_{i, t}, \pi_{i, t}\right)\right)$

entailing:

$$
\left(r_{i, t}-1\right)=\frac{-X_{i, t}-\chi_{i, t}\left(M_{i, t}+S_{i, t}{ }^{\prime}\right)}{\chi_{i, t} M_{i, t}{ }^{\prime}}
$$

This expression can be simplified. For one sector, the consumer's surplus is:

$$
S_{i, t}\left(P_{i, t}\right)=U_{t}\left[d_{i, t}\left(P_{i, t}\right)\right]-P_{i, t} d_{i, t}\left(P_{i, t}\right)
$$

The surplus is derived in relation to the price:

\footnotetext{
${ }^{13}$ On this point see Coughlin (1986, p. 28), and the "redistributive reputations" each candidate is supposed to have. Some analyses are even based on this criterion: Magee, Brock and Young's hypothesis (1989), for example, is that there exist two lobbies, one allied to capital, one to labour.

${ }^{14}$ In this case $r_{i, t}=\hat{r}_{i, t}$.

${ }^{15} \Pi_{i}\left(P_{i}\right)$ is the rent coming from the specific sector. With Hotelling lemma, we have: $\frac{d \Pi_{i}}{d P_{i}}=X_{i}$; with $X_{i}$ the domestic quantity produced by sector $i$.
} 


$$
\begin{aligned}
& \frac{d S_{i, t}}{d P_{i, t}}=U^{\prime}{ }_{t}\left[d_{i, t}\left(P_{i, t}\right)\right] \cdot d_{i, t}^{\prime}\left(P_{i, t}\right)-P_{i, t} d_{i, t}^{\prime}-d_{i, t}\left(P_{i, t}\right) \\
& \frac{d S_{i, t}}{d P_{i, t}}=d_{i, t}^{\prime}\left(P_{i, t}\right)\left[U^{\prime}{ }_{t}\left[d_{i, t}\left(P_{i, t}\right)\right]-P_{i, t}\right]-d_{i, t}\left(P_{i, t}\right)
\end{aligned}
$$

A unit of standard good (price equal to 1) is produced with a labour unit, we have :

$\left[U_{t}^{\prime}\left[d_{i, t}\left(P_{i, t}\right)\right]-P_{i, t}\right]=0$,

entailing : $\frac{d S_{i, t}}{d P_{i, t}}=-d_{i, t}$

We rewrite :

$$
\left(r_{i, t}-1\right)=\frac{-X_{i, t}-\chi_{i, t}\left(M_{i, t}-d_{i, t}\right)}{\chi_{i, t} M_{i, t}{ }^{\prime}}
$$

The imports correspond to demand minus supply, thus we have:

$$
\left(r_{i, t}-1\right)=\frac{-X_{i, t}-\chi_{i, t}\left(-X_{i, t}\right)}{\chi_{i, t} M_{i, t}{ }^{\prime}}
$$

hence:

$$
\left(r_{i, t}-1\right)=\frac{\left(\chi_{i, t}-1\right) X_{i, t}}{\chi_{i, t} M_{i, t}^{\prime}}
$$

which is the writing of the tariff announced to the lobbies and corresponds to the sectorial performance announced to them, i.e. $y^{16}$.

Case 2. The policy announced to the lobbies is totally determined within the framework of the intertemporal political game, according to re-election constraints.

These two cases do not amount to antinomic approaches since the endogenous determination (second case) can include case 1 (with lesser precision) and extend to all types of lobbies including non industrial ones.

In the first case: $C_{i, t}=\phi_{i, t} \cdot \omega_{i, t}$, with $\omega$ the lobby welfare (representative) and $\phi$ representing the lobby contribution plan. In the second case: $C_{i, t}=\lambda_{i, t} \chi y^{a}$, where $\chi$ is the part, in the population, of the productive sectors organised in lobbies, $\lambda$ a positive parameter representing the lobbies'sensitivity to announcements $\left(y^{a}\right)$ made by the candidate.

\footnotetext{
${ }^{16}$ As in the original Grossman and Helpman (1994) paper, and its reformulation by Ederington and Minier (2008).
} 
We here consider that a lobby feels concerned only by the policy applied to the sector to which it belongs. This is a traditional hypothesis in this literature, which may seem restrictive $^{17}$ but has been proved acceptable with regard to reality (Panagariya and Findlay 1996, p. 269).

\subsection{The election phase}

At the next period $(t+1)$, the outgoing candidate's re-election will depend on the evolution of the contributions she will be capable to collect as support to her candidacy as well as on the evolution of social welfare.

Note that the lobby's characteristics are seen as purely static, whereas the incumbent's is dynamic. This difference in treatment can be justified by the fact that policies being shortlived, the capital always exerts its lobbying activity according to its short-term interests (Pecorino 1997, p. 92). Conversely, a political party life span can be considered infinite.

The variation of the likeliness of the outgoing candidate (incumbent)'s election reads:

$$
\dot{\rho_{t+1}}=(1-\alpha) \dot{C_{t+1}}+\alpha \dot{W}_{t+1}
$$

with $\alpha \in[0 ; 1]$, depending on the proportion of the population working in politically organised sectors (like in Grossman and Helpman, 1994).

The lobbies modify their contributions according to the gap between the candidate's effective competence in their field ( $y$, measuring the performance of sectorial policies implemented) and the previous annoncement that their interests or sectorial claims could be satisfied. $\left(y^{a}\right)$ :

$$
\dot{C_{t+1}}=\mu\left(y-y^{a}\right)
$$

parameter $\mu$, positive, being the lobbies's sensitivity to deception (this is how we will, from now on, call a gap between promises and achievements). We consider a lobby as representative. This hypothesis may seem strong (with as a consequence a market power of the lobby), yet it is not contradictory with the framework chosen (as it would be should the lobbying be informative $)^{18}$.

For the population, the variation of welfare depends on the gap between the competence announced to the candidate $\left(x^{a}\right)$ and the one effectively exerted $(x)^{19}$ :

$$
\dot{W}_{t+1}=v\left(x-x^{a}\right)
$$

\footnotetext{
17 Verreydt and Waelbroeck (1982) give the example of the iron industry whose protection search can be countered by the pressure of much iron-consuming industries (Verreydt and Waelbroeck 1982, p. 388). More globally speaking, see Grossman and Helpman (1994, p. 849), for a discussion of this hypothesis.

${ }^{18}$ To make this point clearer see for example Prat (2002, pp. 163-164), who constructs a multiple lobbies model of "nondirectly informative advertising".

${ }^{19}$ This formulation implies myopic voters, reacting with regard to deception. Such behaviour has received strong empirical foundations (see Hibbs, 2006).
} 
with parameter $v$, positive, being the voters' sensitivity to deception. Any incumbent will be considered in a way all the harsher as he will have promised much. From now on, it will be supposed that $x^{a}$ is fixed at the level which maximizes its effect but that it will not be equal to 1 for all that. Indeed the credibility of a total competence announcement is weak. As an illustration, let's quote the "deal with the Italians" suggested by Silvio Berlusconi during the May 2001 campaign, in which he pledged not to run again in 2006 if he had not fulfilled at least four out of his five main electoral promises. As our analysis goes, that told the voters: $x^{a} \geq 0,8$.

Let's also note that from the dynamic point of view $x^{a}$ will be variable depending on the candidates, the commitments and the past positions influencing the credibility of the annoncements (for common assumptions on this point, see Aragones et al. 2007, or Callander and Wilkie 2007).

From now on we suppose that the lobbies'sensitivity to deception is higher than the voters' $(\mu>v)$, lobbies being usually better informed (and having more incentive to be informed) than the population for stakes that concern them directly. Consequently they have a better memory and a higher capacity of reprisal ( $c f$. Baron, $1994^{20}$ ).

\section{Equilibrium}

\subsection{The programme}

The candidate will try to maximize both the probability of an election in the first period and her evolution in the second period. Her utility function reads ${ }^{21}$ :

$$
G_{t}=\rho_{t}+\dot{\rho_{t+1}}
$$

Which she will try to maximize under the following constraints:

$$
\begin{array}{ll}
\text { (6a) } & \rho_{t}>\frac{1}{2}+k \\
\text { (6b) } & \dot{C_{t+1}}+\dot{W}_{t+1} \leq \dot{Y} \\
\text { (6c) } & x \leq L(1-\chi y y)
\end{array}
$$

\footnotetext{
${ }^{20}$ Baron (1994) distinguishes between informed and non informed voters. The latter, contrary to the former, can be influenced by the campaign expenses. It is consistent to consider that these two types of voters coexist in the electorate. Conversely, concerning the lobbies, their members are linked by the defence of a well-defined shared individual interest; concerning this objective, around which their relations with politicians are organized, one cannot consider that the lobby members are non informed or susceptible to the government's influence.

${ }^{21}$ To make reading easier, we omit the candidate's actualisation rate, as taking it into account produces only intuitive extra results.
} 
The first constraint comes first and foremost for the candidate: indeed, in order to be reelected one must first be elected; $k \in|0,1 / 2|$ represents here the security margin desired by the candidate (who also shows a preference for the present) ${ }^{22}$. The second constraint is the one of the ressources available in the economy: ceteris paribus, the sum of the increase of contributions and of the increase in the population's welfare (expressed in the form of surplus) cannot be higher than the total growth of the economy $(\dot{Y})$. Indeed, the more it will be yielded to the lobbies' claims (whose counterparts are the contributions allotted to the candidates), the less (other) possibilities of redistribution granted by the economic growth will remain ( $c f$. Bhagwati's DUPs, 1982) ${ }^{23}$.

The last constraint imposed to the elected candidate is notably the one of the time she devotes to the welfare of the voters. The exercise of her competence, $x$, by the elected candidate depends on the time ( $L \in[0 ; 1]$ ) she devotes to them. However this competence exerted for the benefit of the voters is limited by the competence exerted for the benefit of lobbies $(y)$. Even if we consider that the definition of sectorial policies is not time consuming, since it only respects given commitments, there is no denying that any concession made to lobbies diverts productive resources which could have been employed in a more effective way in relation to voters. Depending on $\chi$, the proportion of global population that the lobby represents, the political effort will be more or less costly.

In other words, if $L \in] 0,1]$ and $\chi$ and $y \in] 0,1[$, the performance vis-a-vis the voters depends on the time the incumbent devotes and on the DUPs: $x \in] 0,1[$. This third constraint is easily explained if the four extreme cases of behaviour are studied:

(i) If $L=0$, the incumbent doesn't care about the voters at all: $x=0$;

(ii) If $L=1$ and $y=0$, the whole effort is made in direction of the voters and the DUPs are absent : $x=1$;

(iii) If $\chi=0$, there are no lobbies, the effort in direction of the voters results directly in performance : $x=L$;

(iv) Finally, a specific situation can be considered where a lobby represents the whole population, thus $\chi=1$. So the politicians doesn't have to make efforts in direction of the electorate (which does not exist as such), there is no checking force and $y$ must be equal to 1 . The constraint generates $x=0$.

\subsection{Solutions and interpretations}

In the first case (announces to the lobbies, $y^{a}$, determined ex-ante), the programme resolution is a classical resolution in $\mathrm{IR}^{2}$. In this case, the model resolution brings the following solutions:

$$
x=L \frac{-\mu+\chi \mu y^{a}+\chi v x^{a}+\chi \dot{Y}}{\nu L \chi-\mu}
$$

\footnotetext{
${ }^{22}$ As parameter $k$ does not influence the results, we will not consider it afterwards.

${ }^{23}$ Laband and Sophocleus's (1988) analysis illustrates this constraint. The authors study the loss of welfare stemming from rent-seeking. Taking economic growth as the welfare criterion and the number of lawyers in exercise as proxy of lobbying, they show that rent-seeking has taken $22.6 \%$ off the US GNP in 1985.
} 


$$
\begin{aligned}
& y^{a}=f\left(\frac{(\chi-1) X}{\chi M^{\prime}}\right) \\
& y=L \frac{-\mu y^{a}+L v-v x^{a}-\dot{Y}}{v L \chi-\mu}
\end{aligned}
$$

In the second case, $y^{a}$ is completely endogenous. The resolution is done in $\mathrm{IR}^{3}$. We hereafter concentrate on this case as it is a more general one.

The second term of the utility function takes into account, from equations (2), (3) and (4), the cost of lying. Here, the cost of lying is expressed in relation both with the electorate and the lobbies (considering deception vis-a-vis the lobbies is an innovative aspect of our approach). The cost of lying results in a diminution of the likeliness of re-election, which solves the all or nothing problematics in the sanction of lying in the polls ${ }^{24}$.

Under the above hypotheses, the model resolution entails the following solutions:

$$
x=L \frac{\mu(1-\lambda)+\chi \lambda\left(v x^{a}+\dot{Y}\right)}{\lambda(L \chi v-\mu)}
$$

(7b) $\quad y^{a}=\frac{1}{\chi \lambda}$

$(7 \mathrm{c})$

$$
y=-\frac{\mu+\chi \lambda\left(v\left(x^{a}-L\right)+\dot{Y}\right)}{\chi \lambda(L \chi v-\mu)}
$$

Based on these expressions, three interesting results can be declined. First, $y$ will always be superior to $x .^{25}$ In other words, the lobbies' interests are better served than those of the population considered as a whole. Beyond the traditional conditions of the lobbies' efficiency (small size, concentration, specificity of the factors, etc.), this result justifies the rationality of being organised in lobbies: what would be the interest of collective action if it did not allow for advantages compared to the rest of the population?

\footnotetext{
${ }^{24}$ As opposed for instance to Aragones et al. (2007) who suppose that the sanction of political lies is to be never believed again.

${ }^{25}$ For space reasons, detailed results are not provided here but an appendix where they are demonstrated is accessible on request to the authors.
} 
Second, the model verifies the Olsonian condition relative to the organisation of pressure groups ( $c f$. Olson, 1966): there is a threshold, $\tilde{\chi}$, to a lobby's size (represented by the proportion of the population belonging to the group), such that, under the threshold when the lobbies'size increases, so does the candidate's effort in their favour ${ }^{26}$. In this case the small size condition is fulfilled and allows the lobbies to be efficient. When their size increases the candidate pays them more attention (depending on the economic "weight" represented) ${ }^{27}$. This threshold, though differently expressed and emerging differently, can also be found in Magee (2002). Hence, in our setting, lobbie's formation can be considered as partly endogenous. ${ }^{28}$ Conversely, beyond this threshold, the lobbies are too important and they lose their characteristics. In this case, political support will be expressed in the same way as for voters at large $\mathrm{e}^{29}$.

Third, it appears, logically, that when the candidate's workload increases, the policy implemented first deals with the population's welfare, any extra work being done to the detriment of lobbies (we have, respectively : $\frac{\partial x}{\partial L}>0 ; \frac{\partial y}{\partial L}<0$ ). This point illustrates clearly the antagonism between the lobbies and the population which is also the opposition between vested interests and general interest.

\section{The dynamics of electoral promises}

As defined above, the word deception expresses the gap between the candidate's promises and her achievements, whether to the population as a whole or to the lobbies. In this section, we show the conditions on which the electoral candidates can make promises without fulfilling, once they have been elected, the contract made with the voters and political supporters during the campaign. First we analyse the impact of promises on the policies implemented, then the impact of the agents' reactions to deception, finally the very dynamics of deception.

\footnotetext{
${ }^{26}$ This means that the Olsonian condition, rather than a traditional postulate, is endogenous to the model.

${ }^{27}$ The small size is the main microeconomic condition for the constitution of a lobby. In all the literature relative to lobbying, a near consensus has been agreed around this point. Which is what allows Wellisz and Wilson (1986, p. 367 , p. 372) to write that a group can meet its objectives even though it doesn't have any other advantage than its small size ; for a similar reasoning see also Becker (1983, p. 385 and p. 395). From a rather macroeconomic point of view, Olson (1982) considers that stable societies with unchanged boundaries tend to generate more organizations for collective actions. A recent study by Coates, Heckleman and Wilson (2007) confirms Olson's view: socioeconomic development and nations' stability (captured through proxies as time since initial take off date, last institutional upheaval and last violent turmoil) are key factors to explain group formation.

${ }^{28}$ Magee presents a model on endogenous trade policy and lobby formation focusing on the interactions between an incumbent and a single lobby. The cost for a member of the lobby to free ride is supposed to be an infinite reversion to the noncooperative solution. In this framework it is shown that increasing the number of the member of the group generates a free-rider problem only when the number of firms (endogenously determined) is sufficiently large (Magee, 2002, p. 457 and p. 467).

${ }^{29}$ The lobby not being efficient any more in its rent seeking activity, the political support of its members is expressed through the vote (like big size groups such as trade-unions or consumers'unions).
} 
In the first place, we consider the sensitivity of the policies implemented in relation to the promises made to the voters. From (7a), we get: $\frac{\partial x}{\partial x^{a}}<0$. So the policies led vis-a-vis the population are all the weaker as the promises were important. This a priori paradoxical result is an important contribution of this paper, the explanation of which stems from the time separation between promises and achievements that our model allows to highlight. In fact, the higher the promises, the less accessible. Rather than trying to reduce the gap later, it gets less costly for the political decision-maker to seek political support from the lobbies (besides we verify $\frac{\partial y}{\partial x^{a}}>0$ ). This situation is notably linked to the (realistic) hypothesis of the voters' inferior sensitivity to deception ( $\mu>v, c f$. Baron, 1994). This result is confirmed by the lobbies tending to benefit from an increase of the ressources available, compared to voters $\left(\frac{\partial y}{\partial}>0\right.$ and $\left.\frac{\partial x}{\partial}<0\right)$.

$\partial \dot{Y} \quad \partial \dot{Y}$

The commitments to lobbies are endogenous, so one can not apply the same analysis as for promises made to voters. Yet it is possible to study the impact on the policies implemented of the lobbies' sensitivity to announcements. One can show that: $\frac{\partial y}{\partial \lambda}<0$, which can be interpreted as follows: when the lobbies'sensitivity to announcements increases, all contributions unchanged, the announcements can decrease; from then on, deception being constant, the sectorial policies implemented decrease. That we have $\frac{\partial x}{\partial \lambda}>0$ testifies to the antagonism between the lobbies and the population.

Second, we analyse the impact of sensitivity to deception on the policies led in the direction of the two types of agents the candidates are related to (i.e. the lobbies and the population). From the previous results we can deduce that, on the condition that $\chi<\tilde{\chi}$, we have $\frac{\partial y}{\partial \mu}>0$.

In other words, if the lobbies verify the Olsonian condition of political efficiency (cf. supra), then the candidates will tend to try to satisfy them all the more so as the lobbies will be sensitive to the gap between the announcements and the efforts really made. So, relatively small lobbies will tend all the more to contribute to the candidates'campaign efforts (another form of the condition of efficiency linked to a small size). 
On the other hand, except if the work done by the candidates is close to nought, the competence exerted by the candidates, once elected, will react positively to the electorate's sensitivity to unkept promises (we have : $\frac{\partial x}{\partial v}>0$ for $L$ different from nought ${ }^{30}$ ). But we have: $\frac{\partial x}{\partial v} \leq 0$ when $L$ tends to nought. This result can be understood intuitively if we reason $a$ contrario: let's imagine that the government works very little for the population even though the population's characteristics do not interfere with the decisions they make (in the model terms: with the competence they exert) once in power. As a corollary, given the constraint (6c), we can remark that if the government strongly favours the lobbies as compared to the population, then it is likely that the competence exerted will have no regard whatever for the population.

Third and last, we consider the results relative to the deception undergone by the agents. The deception vis-a-vis the agents reads like the gap between what was promised and what is implemented, for the voters $T \equiv x^{a}-x$, and for the lobbies $\tilde{T} \equiv y^{a}-y$. The analysis will be based on the elasticities, which allows a comparison of the variations and makes the results more directly interpretable.

We first remark that $\frac{\partial T}{\partial L} \cdot \frac{L}{T}<0$ only if $L>\bar{L}$, which means, in the manner of $\frac{\partial x}{\partial v}>0$ that the relation between work increase and deception decrease is only valid if the government really cares about the population. We remark next that $\frac{\partial \tilde{T}}{\partial \chi} \cdot \frac{\chi}{\widetilde{T}}>0$. So deception vis-a-vis the lobbies tends to increase when their political efficiency decreases (see the threshold relative to the Olsonian condition above). The larger part of the economy they represent, the less efficient they are. Besides, it can be noticed that the more sensitive to the announcements the lobbies are, the greater tendency to deceive them the decision-makers will have $\left(\frac{\partial \tilde{T}}{\partial \lambda}>0\right)$, so as to take in a maximum amount of contributions from a relatively not reluctant political support.

A second interesting result concerning deception with regard to the lobbies is that, when the lobbies'sensitivity to deception increases, they tend to be less deceived $\left(\frac{\partial \tilde{T}}{\partial \mu} \cdot \frac{\mu}{\tilde{T}}<0\right)^{31}$. Let's note that these two results are complementary rather than contradictory, as the lobbies'sensitivity to deception can counterbalance their sensitivity to announcements.

${ }^{30}$ More precisely for $L>\bar{L}$, with $\bar{L}=\frac{w}{1-\chi w \frac{y}{x}}$.

31 Let's note that the lobbies'sensitivity to deception has no impact on deception vis-a-vis the voters $\left(\frac{\partial T}{\partial \mu} \cdot \frac{\mu}{T}=0\right)$, which maintains margins of manœuvre fot the decision-maker. It's actually the contrary for the population, in relation to which deception decreases when its sensitivity to deception increases. Here's the explanation: when the candidate is under constraint from a population more sensitive to deception, which restricts the most "unachievable" promises, margins of manœuvre appear on the lobbies' side, which allows her to receive extra contributions. 
Now, concerning the sensitivity of deception vis-a-vis the electorate, we have $\frac{\partial T}{\partial v} \cdot \frac{v}{T}<0$ for $L>\bar{L}$, which means that when the government works at least a minimum for the population, it deceives them less when they become more sensitive to deception (the disciplining device is valid only if the incumbent does not rely entirely on the lobbies). For the lobbies, the condition of sign of $\frac{\partial \tilde{T}}{\partial v} \cdot \frac{v}{\tilde{T}}$ is the exact opposite of the previous one (thus, when you must deceive the population less, the lobbies are mechanically penalised for it: deception against them increases). By way of consequence, we also find that the higher the announcements $\left(x^{a}\right)$ the more deceived the population (the more you promise the less you keep). A final result concerns the resources constraint. We demontrate that $\frac{\partial T}{\partial \dot{Y}} \cdot \frac{\dot{Y}}{T}>0$ and $\frac{\partial \tilde{T}}{\partial \dot{Y}} \cdot \frac{\dot{Y}}{\widetilde{T}}<0$, which can be interpreted as : when growth improves you deceive the population more and the lobbies less. Consequently the lobbies are the winners of growth; vis-a-vis the ressource, the antagonism between vested and general interest clearly appears again. This result is also a novation of this paper, as it can not appear in a static framework.

\section{Conclusion}

This article offers a framework for analysing the dynamics of election promises, focusing on deception vis-a-vis voters and lobbies. This dual deception is an innovative aspect in the literature on lobbying. Global and sectorial policies (for the population and for the lobbies) maximize the politician's objective function at different levels. In equilibrium, the policy directed to the lobbies will always be more favourable than the policy directed to the population. Thus the lobbies appears as the winner of the political game.

This global result must not hide the nuances that the two-period model adds to the more traditional vision of the political-economic interactions characteristic of the endogenousness of economic policies.

The model presented offers a complementary vision of the Olsonian condition. According to that condition, a lobby's political efficiency is inversely proportional to its size. This condition, almost unanimously accepted in the literature, makes of a small size the main condition for a lobby's constitution.

In the model, the lobby is characterised by the proportion of global population that it represents. In consequence, when this proportion increases the lobby becomes less efficient. But this applies as far as the lobby carries the basic characteristics of a lobby, i.e. as long as this proportion is small. Thus, from a certain level, the group considered does not act as a lobby any longer; its political strength appears in a different way (votes, opinion polls, i.e. like the rest of the population ${ }^{32}$ ).

\footnotetext{
${ }^{32}$ By example if we consider that the lobby represents almost all the population, its influence will be only considered in a uniquely electoral perspective.
} 
Consequently, the incumbent will only take the lobby's characteristics into account if the condition of political efficiency is fulfilled. Thus a policy in favour of the lobby will depend positively on its sensitivity to deception only if the group is under a given size (the difference between potential and active lobby on which the endogenous nature of lobbying is founded in the model can be found here again).

At the level of the electorate the characteristics are stable. But for the incumbent to take these characteristics into account, she needs first to have a minimum interest in the electorate (which translates into a level of minimum effort in favour of the population). It's from this threshold of effort that the sensitivity of the electorate to deception will be taken into consideration. So beyond this threshold, an increase of the sensitivity to deception improves the policy implemented for the population, and in the same condition this policy depends positively on the time devoted by the incumbent to the population.

The sensitivity to announcements clearly highlights the antagonistic interest of lobbies and population. The more sensitive to announcements the lobby's contributions are, the more deceived it is (and the less deceived the population is) whereas the more announcements of a favourable policy are made to the population, the more it is deceived (and the less the lobby): the more you promise the less you keep.

But the analysis also highlights the conditions on which deception can be exerted. From these, it can be shown that really utopian promises do not pay. Indeed, in the model framework, the lobbies'sensitivity to deception counterbalances their sensitivity to announcements, creating a disciplining device for the decision-maker.

The antagonism shows particularly clearly concerning the ressource. When the growth of global wealth increases, the policy in favour of the population deteriorates whereas the action in favour of the lobbies improves. The more resources you have, the more beneficial to the lobbies the redistribution.

It's the same for deception: when the global wealth increases, deception vis-a-vis the voters grows and deception vis-a-vis the lobby decreases. This result can be linked to the fact that the economic growth (assessed in different forms) is one of the main variables of political support. Thus, the better the growth gets, the more likely to be re-elected the incumbent will be; this re-election going along with a growing closeness, as the election cycles go by, to the lobbies (more favours, less deception). It is then logical for the lobbies to prefer that the incumbent keep her position. A lobby's influence on the likeliness of election can notably explain why incumbents get as an average more contributions than their contenders.

This difference in contributions is demonstrated by tests done on the US Congress elections (Stratmann 1995, p. 132). This demonstration is questionable as it is contradictory with the approach of electoral competition since it implies that the incumbents can change their stances to get them closer to their contributors (Mueller and Stratmann 1994, p. 65). Our analysis shows how this "rapprochement" is actually endogenous itself.

For future research it seems promising to distinguish between two voters' groups (informed and non informed) and make their respective parts endogenous according to deception (a deceived voter tending to be more informed) for elections to come and to analyse the consequences on the model equilibrium values. 


\section{References}

Aragonès E., Palfrey Th., Postlewaite A., 2007, "Political reputations and electoral promises", Journal of the European Economic Association, 5, 846-884

Ansolabehere S., de Figueiredo J. M., Snyder Jr J. M., 2003, "Why is There so Little Money in US Politics", Journal of Economic Perspectives, vol. 17, n¹, 105-130

Austen-Smith D., Banks J. S., 1989, "Electoral accountability and incumbency", in Models of strategic choice in politics, Peter Ordershook (eds.), University of Michigan Press

Austen-Smith D., Wright J. R., 1992, "Competitive Lobbying for a Legislator's Vote", Social Choice and Welfare, 9, 229-257

Banks J. S., 1990, "A Model of Electoral Competition With Incomplete Information", Journal of Economic Theory, 50, 309-325

Barro R. J., 1973, "The control of politicians: an economic model", Public Choice, 14, 19-42

Baron. D. P., 1994, "Electoral Competition With Informed and Uninformed Voters", American Political Science Review, 88, 1, 33-47

Becker G. S., 1983, "A Theory of Competition Among Pressure Groups for Political Influence", Quarterly Journal of Economics, XCVIII, 3, 371-400

Bennedsen M., Feldmann S. E., 2006, "Informational lobbying and political contributions", Journal of Public Economics, 90, 631-656

Bhagwati J. N., 1982, "Directly Unproductive, Profit-seeking (DUP) Activities", Journal of Political Economy, 90, 5, 988-1002

Baldwin R. E., 1982, "The Political Economy of Protectionism", in J. Bhagwati, Import Competition and Response, University of Chicago Press, 263-292

Bernheim B., Whinston M., 1986, "Menu auction, ressource allocation and economic influence", Quarterly Journal of Economics, 101, 1-31.

Browning E. K., 1974, "On the Welfare Cost of Transfers", Kyklos, 27, 374-377.

Callander S., Wilkie S., 2007, "Lies, damned lies, and political campaign", Games and Economic Behavior, vol. 60, 262-286

Coates D., Heckleman J. C., Wilson B., 2007, "Determinants on interest group formation", Public Choice, 133, 377-391

Coughlin P., J., 1986, "Elections and Income Redistribution", Public Choice, 50, 1, 27-91

Ederington J., Minier J., 2008, "Reconsidering the empirical relevance on the GrossmanHelpman model of endogenous protection", Canadian Journal of Economics, 41, 2, 501516

Eicher T., Osang T., 2002, "Protection for sale: an empirical estimation: comment", American Economic Review, 92, 1702-1710

Felli L., Merlo A., 2002, "Endogenous lobbying", CEPR Discussion Paper n`3174, 30 p

Ferejohn J., 1986, "Incumbent Performance and Electoral Control", Public Choice, 50, 5-26

Findlay R., Wellisz S., 1982, "Endogenous tariffs, the Political Economy of Trade Restrictions, and Welfare", in Bhagwati, Import Competition and Response, University of Chicago Press, 223-234

Gawande K., Bandyopadhyay U., 2000, "Is protection for sale ? Evidence of the Grossman Helpman theory of endogenous protection", Review of Economics and Statistics, 82, 139152 
Goldberg P., Maggi G., 1999, "Protection for sale: an empirical investigation", American Economic Review, 89, 1135-1155

Grossman G., Helpman E., 1994, "Protection for sale", American Economic Review, 84, 4, $833-850$

Harrington J. E., 1993, "The impact of reelection pressures on the fulfillment of campaign promises", Games and Economic Behavior, 5, 71-97

Hibbs D., 2006, "Voting and the macroeconomy", in Barry W. Weingast and Donald Wittman éditors, The Oxford handbook of political economy, Oxford University Press

Kee H. L., Olarreaga M., Silva P., 2007, "Market Access for Sale", Journal of Development Economics, 82, 79-94

Laband D, N., Sophocleus J, P., 1988, "The Social Cost of Rent-Seeking : First Estimates", Public Choice, 58, 269-275

Lagerlöf J. N. M., 2006, "A theory of Rent Seeking with Informational Foundations", Discussion Paper Series, CEPR n ${ }^{\circ}$ 5893, $24 \mathrm{p}$

Magee C., 2002, "Endogenous trade policy and lobby formation : an application to the freerider problem", Journal of International Economics, 57, 449-471

Magee S. P., Brock W. A., Young L., 1989, Black Hole Tariffs and Endogenous Policy Theory, Cambridge University Press, 438 p.

Lopez R. A., Matschke X., 2006, "Food protection for sale", Review of International Economics, 14, 3, 380-391

McCalman P., 2004, "Protection for sale and trade liberalization: an empirical investigation", Review of International Economics, 12, 81-94

Mitra D., Thomakos D., Ulubasoglu M., 2002, "Protection for sale in a developing country: democracy versus dictatorship", Review of Economics and Statistics, 84, 497-508

Mitra D., Thomakos D., Ulubasoglu M., 2006, "Can we obtain realistic parameter estimates for the 'protection for sale' model?", Canadian Journal of Economics, 39, 187-210

Mueller D. C., Stratmann T., 1994, "Informative and Persuasive Campaigning", Public Choice, 81, October, 55-78

Olson M., 1966, The Logic of Collective Action, Harvard University Press

Olson M., 1982, The rise and decline of nations : Economic growth, stagflation, and social rigidities, Yale University Press

Panagariya A., Findlay R., 1996, "A Political Economy Analysis of Free-Trade Areas and Customs Unions", in Feenstra, Grossman and Irvine, The Political Economy of Trade Policy, MIT Press, 265-287

Pecorino P., 1997, "Exogenous Tariff Changes with an Endogenous Lobbying Response", Public Choice, 92, 1-2, 91-108.

Peltzman S., 1976, "Toward a More General Theory of Regulation", The Journal of Law and Economics, 211-248

Persson T., Tabellini G., 2000, Political Economics: explaining economic policy, MIT Press

Prat A., 2002, "Campaign spending with office-seeking politicians, rational voters, and multiple lobbies", Journal of Economic Theory, 103, 161-189

Rogoff K., 1990, "Equilibrium Political Budget Cycles", American Economic Review, 80, 2136

Stratmann T., 1995, "Campaign Contributions and Congressional Voting : Does the Timing of Contributions Matter?", The Review of Economics and Statistics, LXXVII, 1, February, 127-136

Tullock G., 1972, "The purchase of Politicians", Western Economic Journal, 10, 354-55 
Wellisz S., Wilson. J. D., 1986, "Lobbying and Tariff Formation : A Deadweight Loss Consideration", Journal of International Economics, 20, 367-375

Wirl F., 1994, "The dynamics of lobbying - A differential game", Public Choice, 80, 307-323 


\section{CESifo Working Paper Series}

for full list see www.cesifo-group.org/wp

(address: Poschingerstr. 5, 81679 Munich, Germany, office@cesifo.de)

2461 Wolfgang Ochel, The Political Economy of Two-tier Reforms of Employment Protection in Europe, November 2008

2462 Peter Egger and Doina Maria Radulescu, The Influence of Labor Taxes on the Migration of Skilled Workers, November 2008

2463 Oliver Falck, Stephan Heblich and Stefan Kipar, The Extension of Clusters: Differencein-Differences Evidence from the Bavarian State-Wide Cluster Policy, November 2008

2464 Lei Yang and Keith E. Maskus, Intellectual Property Rights, Technology Transfer and Exports in Developing Countries, November 2008

2465 Claudia M. Buch, The Great Risk Shift? Income Volatility in an International Perspective, November 2008

2466 Walter H. Fisher and Ben J. Heijdra, Growth and the Ageing Joneses, November 2008

2467 Louis Eeckhoudt, Harris Schlesinger and Ilia Tsetlin, Apportioning of Risks via Stochastic Dominance, November 2008

2468 Elin Halvorsen and Thor O. Thoresen, Parents' Desire to Make Equal Inter Vivos Transfers, November 2008

2469 Anna Montén and Marcel Thum, Ageing Municipalities, Gerontocracy and Fiscal Competition, November 2008

2470 Volker Meier and Matthias Wrede, Reducing the Excess Burden of Subsidizing the Stork: Joint Taxation, Individual Taxation, and Family Splitting, November 2008

2471 Gunther Schnabl and Christina Ziegler, Exchange Rate Regime and Wage Determination in Central and Eastern Europe, November 2008

2472 Kjell Erik Lommerud and Odd Rune Straume, Employment Protection versus Flexicurity: On Technology Adoption in Unionised Firms, November 2008

2473 Lukas Menkhoff, High-Frequency Analysis of Foreign Exchange Interventions: What do we learn?, November 2008

2474 Steven Poelhekke and Frederick van der Ploeg, Growth, Foreign Direct Investment and Urban Concentrations: Unbundling Spatial Lags, November 2008

2475 Helge Berger and Volker Nitsch, Gotcha! A Profile of Smuggling in International Trade, November 2008 
2476 Robert Dur and Joeri Sol, Social Interaction, Co-Worker Altruism, and Incentives, November 2008

2477 Gaëtan Nicodème, Corporate Income Tax and Economic Distortions, November 2008

2478 Martin Jacob, Rainer Niemann and Martin Weiss, The Rich Demystified - A Reply to Bach, Corneo, and Steiner (2008), November 2008

2479 Scott Alan Carson, Demographic, Residential, and Socioeconomic Effects on the Distribution of $19^{\text {th }}$ Century African-American Stature, November 2008

2480 Burkhard Heer and Andreas Irmen, Population, Pensions, and Endogenous Economic Growth, November 2008

2481 Thomas Aronsson and Erkki Koskela, Optimal Redistributive Taxation and Provision of Public Input Goods in an Economy with Outsourcing and Unemployment, December 2008

2482 Stanley L. Winer, George Tridimas and Walter Hettich, Social Welfare and Coercion in Public Finance, December 2008

2483 Bruno S. Frey and Benno Torgler, Politicians: Be Killed or Survive, December 2008

2484 Thiess Buettner, Nadine Riedel and Marco Runkel, Strategic Consolidation under Formula Apportionment, December 2008

2485 Irani Arraiz, David M. Drukker, Harry H. Kelejian and Ingmar R. Prucha, A Spatial Cliff-Ord-type Model with Heteroskedastic Innovations: Small and Large Sample Results, December 2008

2486 Oliver Falck, Michael Fritsch and Stephan Heblich, The Apple doesn't Fall far from the Tree: Location of Start-Ups Relative to Incumbents, December 2008

2487 Cary Deck and Harris Schlesinger, Exploring Higher-Order Risk Effects, December 2008

2488 Michael Kaganovich and Volker Meier, Social Security Systems, Human Capital, and Growth in a Small Open Economy, December 2008

2489 Mikael Elinder, Henrik Jordahl and Panu Poutvaara, Selfish and Prospective: Theory and Evidence of Pocketbook Voting, December 2008

2490 Maarten Bosker and Harry Garretsen, Economic Geography and Economic Development in Sub-Saharan Africa, December 2008

2491 Urs Fischbacher and Simon Gächter, Social Preferences, Beliefs, and the Dynamics of Free Riding in Public Good Experiments, December 2008

2492 Michael Hoel, Bush Meets Hotelling: Effects of Improved Renewable Energy Technology on Greenhouse Gas Emissions, December 2008 
2493 Christian Bruns and Oliver Himmler, It's the Media, Stupid - How Media Activity Shapes Public Spending, December 2008

2494 Andreas Knabe and Ronnie Schöb, Minimum Wages and their Alternatives: A Critical Assessment, December 2008

2495 Sascha O. Becker, Peter H. Egger, Maximilian von Ehrlich and Robert Fenge, Going NUTS: The Effect of EU Structural Funds on Regional Performance, December 2008

2496 Robert Dur, Gift Exchange in the Workplace: Money or Attention?, December 2008

2497 Scott Alan Carson, Nineteenth Century Black and White US Statures: The Primary Sources of Vitamin D and their Relationship with Height, December 2008

2498 Thomas Crossley and Mario Jametti, Pension Benefit Insurance and Pension Plan Portfolio Choice, December 2008

2499 Sebastian Hauptmeier, Ferdinand Mittermaier and Johannes Rincke Fiscal Competition over Taxes and Public Inputs: Theory and Evidence, December 2008

2500 Dirk Niepelt, Debt Maturity without Commitment, December 2008

2501 Andrew Clark, Andreas Knabe and Steffen Rätzel, Boon or Bane? Others' Unemployment, Well-being and Job Insecurity, December 2008

2502 Lukas Menkhoff, Rafael R. Rebitzky and Michael Schröder, Heterogeneity in Exchange Rate Expectations: Evidence on the Chartist-Fundamentalist Approach, December 2008

2503 Salvador Barrios, Harry Huizinga, Luc Laeven and Gaëtan Nicodème, International Taxation and Multinational Firm Location Decisions, December 2008

2504 Andreas Irmen, Cross-Country Income Differences and Technology Diffusion in a Competitive World, December 2008

2505 Wenan Fei, Claude Fluet and Harris Schlesinger, Uncertain Bequest Needs and LongTerm Insurance Contracts, December 2008

2506 Wido Geis, Silke Uebelmesser and Martin Werding, How do Migrants Choose their Destination Country? An Analysis of Institutional Determinants, December 2008

2507 Hiroyuki Kasahara and Katsumi Shimotsu, Sequential Estimation of Structural Models with a Fixed Point Constraint, December 2008

2508 Barbara Hofmann, Work Incentives? Ex Post Effects of Unemployment Insurance Sanctions - Evidence from West Germany, December 2008

2509 Louis Hotte and Stanley L. Winer, The Demands for Environmental Regulation and for Trade in the Presence of Private Mitigation, December 2008 
2510 Konstantinos Angelopoulos, Jim Malley and Apostolis Philippopoulos, Welfare Implications of Public Education Spending Rules, December 2008

2511 Robert Orlowski and Regina T. Riphahn, The East German Wage Structure after Transition, December 2008

2512 Michel Beine, Frédéric Docquier and Maurice Schiff, International Migration, Transfers of Norms and Home Country Fertility, December 2008

2513 Dirk Schindler and Benjamin Weigert, Educational and Wage Risk: Social Insurance vs. Quality of Education, December 2008

2514 Bernd Hayo and Stefan Voigt, The Relevance of Judicial Procedure for Economic Growth, December 2008

2515 Bruno S. Frey and Susanne Neckermann, Awards in Economics - Towards a New Field of Inquiry, January 2009

2516 Gregory Gilpin and Michael Kaganovich, The Quantity and Quality of Teachers: A Dynamic Trade-off, January 2009

2517 Sascha O. Becker, Peter H. Egger and Valeria Merlo, How Low Business Tax Rates Attract Multinational Headquarters: Municipality-Level Evidence from Germany, January 2009

2518 Geir H. Bjønnes, Steinar Holden, Dagfinn Rime and Haakon O.Aa. Solheim, ,Large’ vs. ,Small' Players: A Closer Look at the Dynamics of Speculative Attacks, January 2009

2519 Jesus Crespo Cuaresma, Gernot Doppelhofer and Martin Feldkircher, The Determinants of Economic Growth in European Regions, January 2009

2520 Salvador Valdés-Prieto, The 2008 Chilean Reform to First-Pillar Pensions, January 2009

2521 Geir B. Asheim and Tapan Mitra, Sustainability and Discounted Utilitarianism in Models of Economic Growth, January 2009

2522 Etienne Farvaque and Gaël Lagadec, Electoral Control when Policies are for Sale, January 2009 